\title{
The genetic diversity of ampeloviruses in Australian pineapples and their association with mealybug wilt disease
}

\author{
C. F. Gambley ${ }^{\mathrm{A}, \mathrm{B}, \mathrm{C}}$, V. Steele ${ }^{\mathrm{A}}$, A. D. W. Geering ${ }^{\mathrm{A}}$ and J. E. Thomas ${ }^{\mathrm{A}}$ \\ A Department of Primary Industries and Fisheries, Horticulture and Forestry Science, \\ 80 Meiers Road, Indooroopilly, Qld 4068, Australia. \\ ${ }^{B}$ School of Integrative Biology, The University of Queensland, St Lucia, Qld 4072, Australia. \\ ${ }^{\mathrm{C}}$ Corresponding author. Email: cherie.gambley@dpi.qld.gov.au
}

\begin{abstract}
Pineapple mealybug wilt-associated virus 1 (PMWaV-1), 2 (PMWaV-2) and 3 (PMWaV-3) have been detected in Australian commercial pineapple crops, along with a previously undescribed ampelovirus, for which the name Pineapple mealybug wilt-associated virus $5(\mathrm{PMWaV}-5)$ is proposed. Partial sequences extending from open reading frame $1 \mathrm{~b}$ through to the heat shock protein homologue were obtained for PMWaV-1, -3 and -5 . Phylogenetic analyses of selected regions of these sequences indicated that PMWaV-5 is a distinct species and most closely related to PMWaV-1. The amino acid sequence variation observed in the RNA-dependent RNA polymerase region of PMWaV-1 isolates was $95.8-98.4 \%$ and of PMWaV-3 isolates was 92.2-99.5\%.

In surveys of mealybug wilt disease (MWD) affected crops, none of the four viruses was clearly associated with the disease at all survey sites. A statistically significant association $(P<0.001)$ between the presence of PMWaV-2 and symptoms was observed at one survey site (site 3), but the virus was at a low incidence at the remaining three survey sites. By contrast, although PMWaV-1 and -3 were equally distributed between symptomless and MWD-affected plants at site 3 , there was a statistically significant $(P<0.001)$ association between each of these two viruses and MWD at sites 1 and 4 . At site 2 , there was a statistically significant $(P<0.001)$ association only between PMWaV-3 and MWD. PMWaV-1 was the most commonly found of the four viruses and conversely PMWaV-5 was only occasionally found. Australian isolates of PMWaV-1, -2 and -3 were transmitted by the mealybug species Dysmicoccus brevipes.
\end{abstract}

Additional keywords: Ananas comosus, closterovirid, Closteroviridae, closterovirus, mealybug wilt of pineapple.

\section{Introduction}

Mealybug wilt disease (MWD), a major field disease of pineapple (Ananas comosus var. comosus) worldwide, was first described in Hawaii in 1910 (German et al. 1992), where it is referred to as mealybug wilt of pineapple (MWP). Typically, the leaves of diseased plants redden, lose rigidity, roll downwards at the margin and the tip of the leaf dies; the root tissue also collapses and the plant appears wilted but can recover to produce symptomless leaves (Carter 1933a). In Hawaii, MWD has been shown to reduce fruit yields by $30-55 \%$, depending on the age of the plant at the onset of the disease (Sether and Hu 2002b). In Australia, the total annual value of pineapple production is estimated to be reduced by $10 \%$ as a result of the disease (C. Scott, Golden Circle, pers. comm.).

Early in the twentieth century, an association between mealybugs and MWD was established in Hawaii and it was proposed that symptoms were due to a phytotoxin being released by the insect when feeding (Illingworth 1931; Carter 1933a , 1933b, 1945; Carter and Collins 1947). Two species of mealybugs were most commonly associated with the disease, namely Dysmicoccus brevipes (Cockerell) and D. neobrevipes (Beardsley) (Carter 1933a, 1933b; Ito 1959). In Australia, only
D. brevipes is known to occur and only females have been observed (Williams 1985).

Subsequent research implicated a latent transmissible factor, most likely a virus, as the cause of MWD (Ito 1959). In 1989 , filamentous virions typical of a member of the family Closteroviridae (subsequently referred to as closterovirids), and dsRNA, a replicative intermediate of many genera of plant viruses, were detected in pineapple (Gunasinghe and German 1989). Using monoclonal antibodies, two serotypes of the virus were detected by immunosorbent electron microscopy (ISEM) (Hu et al. 1996). Substantial portions of the genomes of these two viruses, now named Pineapple mealybug wilt-associated virus 1 (PMWaV-1) and Pineapple mealybug wilt-associated virus 2 (PMWaV-2), have been sequenced (Melzer et al. 2001; Sether et al. 2001). PMWaV-1 and -2 have also been classified in the genus Ampelovirus, whose type species is Grapevine leafrollassociated virus 3 (GLRaV-3) (Melzer et al. 2001; Sether et al. 2005a).

The presence of a further two ampeloviruses, Pineapple mealybug wilt-associated virus 3 (PMWaV-3) and Pineapple mealybug wilt-associated virus 4 (PMWaV-4), has been recently reported (Sether et al. 2005b). Wakman et al. (1995) also 
observed two distinct serotypes of closterovirid from Australian pineapples, which were named Pineapple closterovirus A and $\mathrm{B}$, but it is not known how these viruses relate to the viruses described from Hawaii. During this study, a bacilliform-shaped virus was also detected in pineapples in Australia (Wakman et al. 1995), which from particle size and morphology, and later, sequence analysis (Thomson et al. 1996), was most likely a member of the genus Badnavirus. PMWaV-1 was detected in a small number of samples of Australian pineapples (Sether et al. 2001) but PMWaV-2, -3 and -4 have not previously been reported.

In Hawaii, PMWaV-2 is thought to cause MWD (MWP) but only in combination with mealybug infestation (Sether and $\mathrm{Hu} 2002 a$ ). Field studies showed that the presence of either agent alone was insufficient to induce symptoms (Sether and $\mathrm{Hu} 2002 a$ ). Although the incidence of PMWaV-1 in Hawaiian pineapple proprietary selections and hybrids was reported to be higher than PMWaV-2, it is often present in plants irrespective of MWD symptoms and is thus not considered to be a factor in the aetiology of MWD (Sether and Hu 2001; Sether et al. 2001). The presence of PMWaV-3 alone or in combination with mealybugs was not associated with MWD symptoms in studies conducted in Hawaii (Sether et al. 2005a).

By analogy with other vegetatively propagated crops, it is likely there is a greater diversity of closterovirids infecting pineapple than is currently known. In grapevine at least eight distinct closterovirids have been identified from plants with leafroll disease (Fauquet et al. 2005). Two distinct closterovirids have been associated with little cherry disease in North America and Europe, namely Little cherry virus 1 and Little cherry virus 2 (Rott and Jelkmann 2001). In this paper, we describe work conducted to investigate the diversity of closterovirids in Australian pineapples. We have confirmed the presence of PMWaV-1, -2 and -3 , and also provide evidence for the existence of a new virus, for which we propose the name Pineapple mealybug wilt-associated virus 5 (PMWaV-5). We have developed a reverse transcription PCR (RT-PCR) assay to detect all four viruses, and using this assay, investigated the aetiology of MWD in Australian pineapples.

\section{Methods}

\section{Virus purifications}

The locations from which virus isolates were obtained are listed in Fig. 1. Virions were purified from $\sim 80 \mathrm{~g}$ of white basal leaf tissue of pineapple cv. Smooth Cayenne clone 10 plants using the method of Wakman et al. (1995) with the following modifications. The extraction buffer was $0.5 \mathrm{M}$ potassium phosphate, $\mathrm{pH} 8.0$, containing $5 \mathrm{~g} / \mathrm{L} \quad \mathrm{Na}_{2} \mathrm{SO}_{4}$ and $40 \mathrm{~mL} / \mathrm{L}$ Triton X-100. Following the first low speed centrifugation, the supernatants were centrifuged over a $200 \mathrm{~g} / \mathrm{L}$ sucrose cushion in a Beckman $45 \mathrm{Ti}$ rotor at $45000 \mathrm{rpm}$ for $90 \mathrm{~min}$. Virions were finally purified in a $\mathrm{CsCl}$ gradient, and fractions with a density of $\sim 1.32 \mathrm{~g} / \mathrm{cm}^{3}$ combined, centrifuged in a Beckman $75 \mathrm{Ti}$ rotor at $50000 \mathrm{rpm}$ for $1 \mathrm{~h}$ and the pellet resuspended in $50 \mu \mathrm{L}$ of $100 \mathrm{mM}$ Tris- $\mathrm{HCl}, \mathrm{pH} 8.5$, containing $10 \mathrm{mM} \mathrm{MgCl}_{2}$.

Virions were also partially purified from 2 to $5 \mathrm{~g}$ of leaf tissue (virus miniprep) essentially as described by Geering et al. (2000) but with the abovementioned extraction buffer. Virions were concentrated through a sucrose cushion in a Beckman $30 \mathrm{Ti}$ rotor at $30000 \mathrm{rpm}$ for $2 \mathrm{~h}$ and pellets resuspended as above using $30 \mu \mathrm{L}$ of buffer.

\section{ISEM}

For ISEM, nitrocellulose-coated electron microscope grids were coated with a mix of polyclonal antisera to Sugarcane bacilliform virus $(4 \times \mathrm{mx}$ supplied by BEL Lockhart, University of Minnesota) and to closterovirids and badnaviruses purified from Queensland (Qld) field pineapple plants (Wakman et al. 1995), each at a dilution of $1 / 1000$ in $50 \mathrm{mM}$ sodium phosphate buffer $\mathrm{pH} 7.5$, for $1-2 \mathrm{~h}$ at room temperature. The grids were then washed twice for $5 \mathrm{~min}$ with the same buffer and incubated with $10 \mu \mathrm{L}$ of virus miniprep at room temperature for $2 \mathrm{~h}$ or overnight at $4{ }^{\circ} \mathrm{C}$. After rinsing with water, the grids were stained with $2 \%(\mathrm{w} / \mathrm{v})$ ammonium molybdate $\mathrm{pH} 5.8$, or $2 \%(\mathrm{w} / \mathrm{v})$ potassium phosphotungstate $\mathrm{pH} 7.0$ and viewed under a $\mathrm{H}-7000$ transmission electron microscope (Hitachi Denshi Ltd, Tokyo, Japan).

\section{RNA extractions}

RNA was extracted from $0.1 \mathrm{~g}$ of basal leaf tissue using either an RNeasy kit (Qiagen, Hamburg, Germany) according to the manufacturer's instructions or using the method below. Plant tissue was macerated in $500 \mu \mathrm{L}$ of Concert Plant RNA Purification Reagent (Invitrogen, Carlsbad, CA) using $2.0 \mathrm{~mm}$ glass beads in a Fast Prep (BIO 101 FP120, Thermo Savant, Savant Instruments Inc., Farmingdale, NY) at $6.5 \mathrm{~m} / \mathrm{s}$ for $45 \mathrm{~s}$. The extract was incubated at room temperature for $5 \mathrm{~min}$, centrifuged at $10000 \mathrm{~g}$ for $30 \mathrm{~s}$ and the supernatant transferred to a fresh tube. The extract was further clarified by centrifugation at $10000 \mathrm{~g}$ for $10 \mathrm{~min}$ at $4{ }^{\circ} \mathrm{C}, 300 \mu \mathrm{L}$ of chloroform and $100 \mu \mathrm{L}$ of $5 \mathrm{M} \mathrm{NaCl}$ added to the supernatant, the tube vortexed briefly and then centrifuged at $10000 \mathrm{~g}$ for $10 \mathrm{~min}$ at $4{ }^{\circ} \mathrm{C}$. To minimise contamination with carbohydrates, RNA was precipitated from the aqueous phase by the addition of equal volumes of isopropanol and salt solution $(0.8 \mathrm{M}$ sodium citrate, 1.2 $\mathrm{M} \mathrm{NaCl}, \mathrm{pH} 7.0$ ) and immediately pelleted by centrifugation at $10000 \mathrm{~g}$ for $10 \mathrm{~min}$ at $4^{\circ} \mathrm{C}$. The pellet was washed with $75 \%$ ethanol, air-dried and resuspended in $30 \mu \mathrm{L}$ of RNAse-free water.

\section{Reverse transcriptase (RT)-PCR}

Random RT-PCR was conducted as described by Gambley and Thomas (2001) on purified virus prepared using the modified method of Wakman et al. (1995). The heat shock protein 70 homologue $(\mathrm{Hsp} 70 \mathrm{~h})$ region of the closterovirid genome was also amplified by RT-PCR using the degenerate primers HSP-P-1 and Tian-P2(M) (Tian et al. 1996; Table 1) using either a virus miniprep or purified virus as template in RT-PCR. First strand cDNA was prepared using either Superscript II (Invitrogen) or Sensiscript (Qiagen) RT following the manufacturers' instructions and with 30-34 pmoles of Tian$\mathrm{P} 2(\mathrm{M})$ to prime the reaction. The PCR contained $2.0 \mu \mathrm{L}$ of cDNA, 10 pmoles of HSP-P-1, 34 pmoles of Tian-P2(M), 3 mM $\mathrm{MgCl}_{2}, 2.5 \mu \mathrm{L}$ of $10 \times$ reaction buffer (Invitrogen), $200 \mu \mathrm{M}$ of each dNTP, 1.5 units of Taq DNA polymerase (Invitrogen) and 


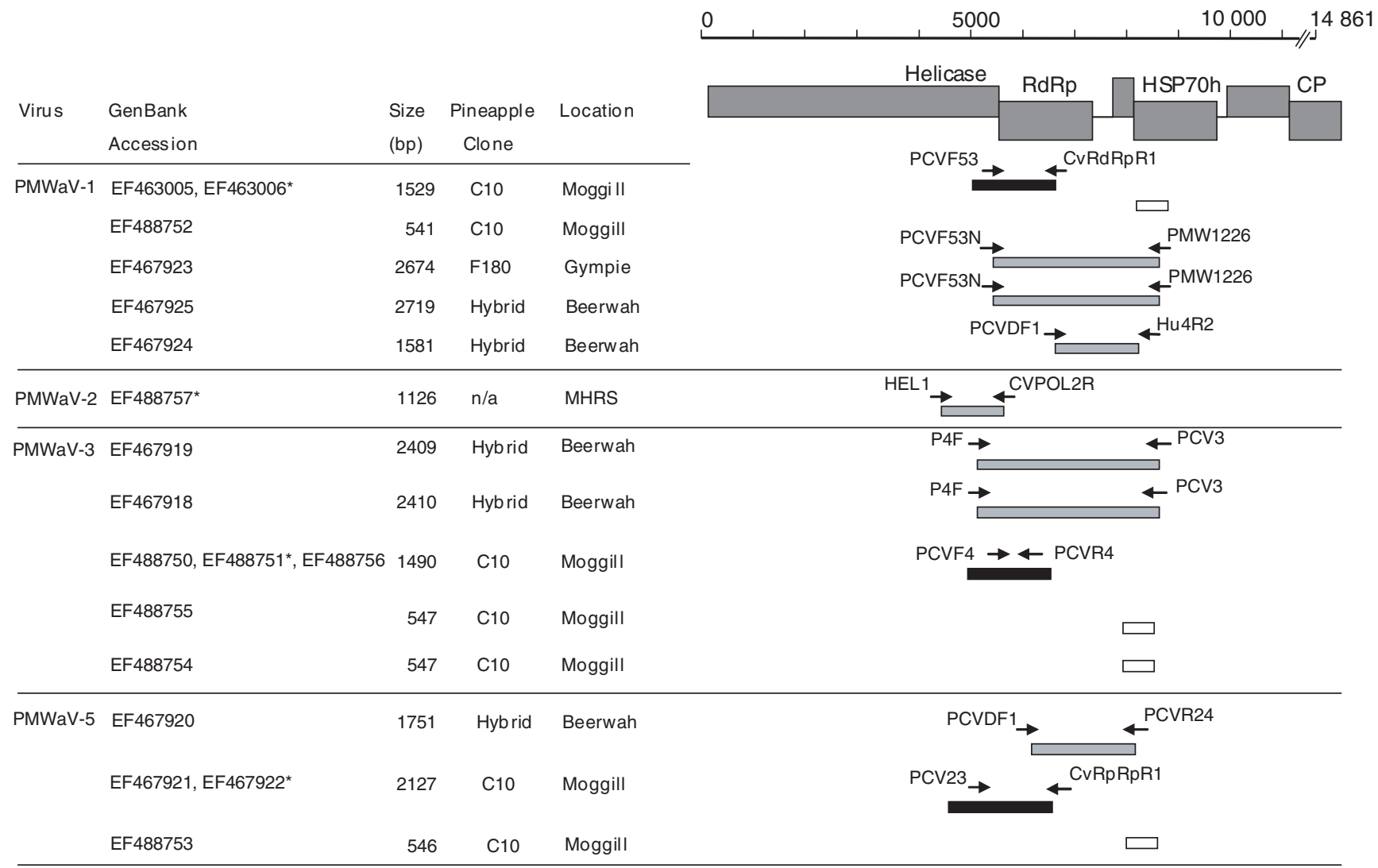

Fig. 1. Positions of reverse transcription (RT)-PCR clones and contigs based on sequence similarities with the complete genome of PMWaV-2. Selected gene products are indicated and include the helicase, RNA-dependent RNA polymerase (RdRp), heat shock protein homologue (Hsp70h) and the coat protein (CP). Sequence contigs that were obtained by extension of random RT-PCR clones are indicated by solid black shading, sequences from RT-PCR using Hsp70h degenerate primers in solid white shading and from RT-PCR using specific primers to link sequence fragments in solid grey shading. The primers used in the generation of fragments and contigs are shown and primer details are listed in Table 1. Virus species, GenBank accession codes and sizes are indicated on the left along with the Ananas comosus var. comosus cv. Smooth Cayenne clone line in which the sequence was detected. The sequence of PMWaV-2 was obtained from A. comosus var. erectifolius. All virus isolates were collected in south-east Queensland and the nearest town to the collection point is listed as the location. The sequences of the plasmid clones used to generate virus-specific probes for molecular indexing are indicated with an asterisk.

Table 1. Primers used for amplification of ampelovirus sequences and/or for the detection of virus isolates

\begin{tabular}{lllll}
\hline Primer & Primer sequence $\left(5^{\prime}\right.$ to $3^{\prime}$ direction) & Genome region & Direction & Virus specificity \\
\hline CVPOL2R & ATGGWAHACWATATTYTGHCC & RdRp & Reverse & Closteroviridae \\
CVRdRpR1 & RAAYTTNSWRCARAARTANGG & RdRp & Reverse & Closteroviridae \\
HEL1 & TCTTACAGATGTCCTGCCGA & Helicase & Forward & PMWaV-2 \\
Hu4R2 & TTCGAGATAMACATCYTTGTTRAA & Hsp70h & Reverse & PMWaV-1 and -4 \\
HSP-P-1 & GGNTTAGANTTCGGNACNAC & Hsp70h & Forward & Closteroviridae \\
PCV3 & TTCGCTCGCAACACAAAAG & Hsp70h & Reverse & PMWaV-3 \\
PCVF23 & ACGGGAGCTAACAGAGAAC & Helicase & Forward & PMWaV-5 \\
PCVF4 & TTGACCCGTCATACGGTGAG & Helicase & Forward & PMWaV-3 \\
PCVR4 & CAATGCCGCGTATAGTTGTTC & RdRp & Reverse & PMWaV-3 \\
PCVF53N & CACAGTCTATTCTCACAA & Helicase & Forward & PMWaV-1 \\
PCVF53 & CTCAGAACGAGAAGAATGAAC & Helicase & Forward & PMWaV-1 \\
PCVDF1 & GGTGGCTTATGARAAKAGDAA & Helicase & Forward & PMWaV-1, -2, -3 and -5 \\
PCVDR1 & GCTCTATCATGGAAHACWATA & RdRp & Reverse & PMWaV-1, -2, -3 and -5 \\
PCVR24 & CACTCACTTGCTGACCG & Hsp70h & Reverse & PMWaV-5 \\
PMW2224 & CATACGAACTAGACTCATACG & Hsp70h & Forward & PMWaV-2 \\
PMW2223 & CCATCCACCAATTTTACTAC & Hsp70h & Reverse & PMWaV-2 \\
Tian-P2(M) & TCRAANGTNCCNCCNCCRAARTC & Hsp70h & Reverse & Closteroviridae
\end{tabular}

A The sequence of primer PMW2223 as published by Sether et al. (2001) contains an error (D. M. Sether, pers. comm.). The correct primer sequence is presented in this table. 
water to a final volume of $25 \mu \mathrm{L}$. Thermocycling parameters were one cycle at $94^{\circ} \mathrm{C}$ for $1 \mathrm{~min}, 35$ cycles at $94^{\circ} \mathrm{C}$ for $30 \mathrm{~s}$, $50^{\circ} \mathrm{C}$ for $30 \mathrm{~s}$ and $72^{\circ} \mathrm{C}$ for $1 \mathrm{~min}$ and finally one cycle at $72^{\circ} \mathrm{C}$ for $3 \mathrm{~min}$.

Combinations of different degenerate and specific primers were used in RT-PCR to extend or join partial genomic clones generated from the random RT-PCR and the Hsp70h-specific PCRs. Additionally, a specific forward primer was designed to a closterovirid helicase sequence derived previously from an Australian pineapple sample (Horlock 2003), which then was used in combination with a degenerate reverse primer, CVPOL2R designed to the conserved RNA-dependent RNA polymerase (RdRp) motif 'POL II' (XQNIXYH) described by Fazeli and Rezaian (2000). All primer sequences are listed in Table 1. For RT-PCR, purified virus or RNA extracts were used as template, Sensiscript or Superscript III RT for cDNA synthesis and either Taq DNA polymerase (Invitrogen), ELONgase DNA polymerase (Invitrogen) or Phusion DNA polymerase (Finnzymes, Espoo, Finnland) for PCR. All enzymes were used according to the manufacturers' instructions.

PCR products were separated in a $1 \%$ agarose gel in $0.5 \times$ Tris-borate-EDTA and visualised by staining with ethidium bromide (Sambrook et al. 1989).

\section{Cloning, sequencing and sequence analyses}

PCR products were ligated into the vector pCR2.1 using a TOPO TA cloning kit (Invitrogen) following the manufacturer's instructions. Sequencing was conducted at the Australian Genome Research Facility at the The University of Qld and sequence editing and assembly was completed using the Vector NTI Advance 10 software package (Invitrogen). Searches of GenBank were conducted using tBLASTX (Altschul et al. 1990).

Amino acid sequences were aligned with CLUSTAL X (Thompson et al. 1997) and genetic distances calculated using the MEGA 3.1 software package (Kumar et al. 2004). Evolutionary trees were inferred using the maximum likelihood method as implemented in the TREE PUZZLE software package (Schmidt et al. 2004) using default settings. Unpublished partial sequences of the RdRp region of $\mathrm{PMWaV}-3$ and the Hsp70 region of PMWaV-4 were kindly provided by J. S. Hu, D. M. Sether and M. Melzer (University of Hawaii). Newly determined sequences were deposited into GenBank and accession codes are listed in Fig. 1.

\section{RT-PCR microtitre plate detection (MTPD) assay of pineapple ampleoviruses}

To simultaneously detect PMWaV-1, $-2,-3$ and -5 , the primers PCVDF1 and PCVDR1 (Table 1) were used. First-strand cDNA was synthesised in a reaction containing $2.0 \mu \mathrm{L}$ of RNA, 10-30 pmoles of PCVDR1, $500 \mu \mathrm{M}$ of each dNTP, $10 \mathrm{mM}$ DTT, $2.0 \mu \mathrm{L}$ of $10 \times$ reaction buffer (Qiagen), 10 units of RNAguard RNase Inhibitor (Amersham Biosciences, Piscataway, NJ), $0.5-1.0 \mu \mathrm{L}$ of Sensiscript (Qiagen) and water to a total volume of $20 \mu \mathrm{L}$. The reactions were incubated at $45^{\circ} \mathrm{C}$ for $1 \mathrm{~h}$. The PCR mix contained $2.0 \mu \mathrm{L}$ of cDNA, $2.5 \mu \mathrm{L}$ of $10 \times$ reaction buffer (Invitrogen), $1.75 \mathrm{mM} \mathrm{MgCl} 2,200 \mu \mathrm{M}$ of each dNTP, 10-30 pmoles of each primer (PCVDF1 and PCVDR1), 1.5 units of Taq DNA polymerase (Invitrogen) and water to a total volume of $25 \mu \mathrm{L}$. Thermal cycling conditions were one cycle at $94^{\circ} \mathrm{C}$ for
$1 \mathrm{~min}$ followed by 40 cycles of $94^{\circ} \mathrm{C}$ for $20 \mathrm{~s}, 46^{\circ} \mathrm{C}$ for $20 \mathrm{~s}, 72^{\circ} \mathrm{C}$ for $30 \mathrm{~s}$ and finally, one cycle of $72^{\circ} \mathrm{C}$ for $5 \mathrm{~min}$.

Digoxygenin (DIG) probes were prepared from cloned cDNA by PCR using the same primers (PCVDF1 and PCVDR1) with a dNTP mix containing dTTP and alkali-stable DIG-dUTP (Roche Diagnostics, West Sussex, UK) at a ratio of $19: 1$. The clones used to prepare the probes were as follows: p53cv2 for PMWaV-1, p21-2812-14 for PMWaV-2, pPCVF4R4 for PMWaV-3 and pF23cvrdrp3 for PMWaV-5. Probes were purified using a QIAquick PCR purification kit (Qiagen) according to the manufacturer's instructions.

The MTPD assay protocol was conducted essentially as described by Sharman et al. (2000) with the following modifications. DIG-labelled probes were diluted 1:500 in DIG Easy Hyb buffer (Roche Diagnostics) and unbound probe removed by two $20-\mathrm{min}$ washes at $70^{\circ} \mathrm{C}$ in $0.1 \times$ standard saline citrate containing $0.1 \%$ sodium dodecyl sulfate.

\section{Disease survey}

To investigate the correlation between MWD and virus infection, four commercial Smooth Cayenne pineapple crops, located in south-east Qld, were surveyed. In the Beerwah and Glasshouse Mountains regions, site 1 was a crop of a commercial proprietary hybrid, site 2 a F180 and site 3 a C30 clonal plant line crop. A second F180 crop was located at Gympie (site 4). Plants were tagged with surveyor's tape, symptoms noted, and one to three young leaves sampled from each plant for virus indexing. Only plants with advanced symptoms of MWD or showing no symptoms of the disease were selected. Plants were indexed for PMWaV-1, $-2,-3$ and -5 by RT-PCR-MTPD. Additionally, plants were tested for PMWaV-1 by tissue blotting immunoassay (TBIA) as described by $\mathrm{Hu}$ et al. (1997) and for PMWaV-2 by RT-PCR as described by Sether et al. (2001). Tagged plants at sites 1 and 2 were inspected again for symptoms 3 months after the first survey.

\section{Viruses present in germplasm collections}

RT-PCR-MTPD was used to index freeze-dried leaf samples obtained from selected germplasm accessions maintained at the Maroochy Research Station (MRS), Department of Primary Industries and Fisheries, Nambour, Qld and the Centre de coopération internationale en recherche agronomique pour le développement (CIRAD), Martinique.

\section{Statistical analyses}

Each plant from the disease survey was rated according to whether MWD symptoms were present and whether either PMWaV-1, -2, -3 or -5 had been detected. From this, a 5-way contingency table of the number of plants in each combination of the five categories was constructed for each site. To test for an association between MWD and virus status, log-linear models were initially fitted separately to data from each site. A stepwise delete process was then used to develop a parsimonious model that best fitted the data by progressively deleting non-significant $(P>0.05)$ terms starting with an initial model including all five main effects and all possible interactions up to 4-factor interactions. At site 3, PMWaV-1 and -3 were present in every plant; therefore, the analysis only assessed the association between disease status and the present or absence of PMWaV-2 and -5 . Preliminary results indicated similar results for sites 1 
and 4 so data for these two sites were combined and reanalysed. In the final models, significant interactions between disease status and the presence or absence of the viruses are of interest. Log-linear modelling was carried out using the 8th edition of GENSTAT for Windows software package (Rothamsted, UK).

\section{Transmission experiments}

A colony of D. brevipes was raised on the fruit of Cucurbita moschata (butternut pumpkin). Ampelovirus-free pineapple seedling test plants for inoculation were obtained from the MRS. Virus indexing of test plants before and 1 month after inoculation was conducted by TBIA (Hu et al. 1997), ISEM and/or RT-PCR-MTPD. Test plants were also monitored for symptoms for a further 2-5 months after inoculation. For the first experiment, a Smooth Cayenne clonal F180 plant collected from Yengarie, south-east Qld, and infected with PMWaV-1 and -3, was used as the inoculum source. Sections of pumpkin skin containing $\sim 40$ mealybugs were placed on detached pineapple leaves in a humid chamber and the mealybugs allowed an acquisition access time of $48 \mathrm{~h}$. The leaves were then transferred to five potted seedlings and the mealybugs allowed an inoculation access time of $48 \mathrm{~h}$ before being killed with insecticide and the plants transferred to the glasshouse.

A second glasshouse transmission experiment was conducted using four potted C10 plants from Moggill, south-east Qld, and infected with PMWaV-1 and -2 as the inoculum source. In this experiment, two clonally propagated plants derived from a single seed were placed adjacent to each of the virus-infected plants. Approximately 200 juvenile mealybugs were transferred to each virus-infected plant using sections of pumpkin skin containing the insects. The skins were removed after 16 days and the mealybugs were allowed to spread naturally between plants.

\section{Results}

\section{Cloning strategies}

At the commencement of this study, no sequences of any closterovirid infecting pineapple had been published and, therefore, in initial cloning experiments, cDNAs amplified by random RT-PCR and RT-PCR of the Hsp70h region using degenerate primers to a range of closterovirids were used. Additional clones were obtained by RT-PCR using primers designed to link or extend the original clones. Using these strategies, 13 ampelovirus-like sequences of $\sim 540-2500$ base pairs (bp) in size were obtained (Fig. 1), all of which had significant similarity in tBlastX searches of GenBank to the helicase, RdRp or Hsp70h regions of the GLRaV-3 genome. In later analyses using pairwise sequence comparisons, 10 of the 13 sequences were highly similar to either PMWaV-1 or -3 .

No clones with close sequence identity to $\mathrm{PMWaV}-2$ were obtained using the methods above. Instead, a $1126 \mathrm{bp}$ DNA fragment (GenBank accession EF488757) was amplified by RTPCR from a MRS germplasm accession of $A$. comosus var. erectifolius cultivar Selvagem 6 and the sequence of this was $98.0 \%$ identical at the nucleotide level to the published isolate of PMWaV-2 from Hawaii (GenBank accession AF283103).

\section{Sequence analyses}

To investigate the relationships of the Australian pineapple viruses, conceptual translations of the cDNA sequences were conducted and comparisons made with regions of the helicase, $\mathrm{RdRp}$, open reading frame (ORF)2 and the Hsp70h of various closterovirids (Table 2).

In the RdRp, four sequences (GenBank accessions EF467923, EF467925, EF467924 and EF463006) had 95.8-98.4\% amino acid (aa) identity to the Hawaiian isolate of PMWaV-1 (GenBank accession AF414119), and were, therefore, considered sequence variants of this species. Three sequences (GenBank accessions EF467919, EF467918 and EF488751) had $>93 \%$ aa sequence identity to each other and the former two overlapped the entire partial genomic sequence of the Hawaiian isolate of PMWaV-3 (752 bp), in which region there was $>92 \%$ aa sequence identity and, therefore, these Australian virus isolates were considered to be this species. An additional two sequences (GenBank accessions EF467920 and EF467922) had $99 \%$ aa sequence identity to each other in a 882 bp overlap, but less than $71 \%$ aa sequence identity to any previously described ampelovirus (Table 2) and thus represent sequence variants of a probable new virus species, for which we propose the name Pineapple mealybug wilt-associated virus 5 (PMWaV-5). In all cases where comparison was possible, aa identities with other closterovirids in the RdRp were reflected in similar identities in the Hsp70h (Table 2), suggesting that the $90 \%$ aa identity in the coat protein, minor capsid protein and Hsp70h for species delimitation (Fauquet et al. 2005) may also be relevant for the RdRp. Dolja et al. (2006) showed that the topology of the phylogenetic trees of the RdRp and Hsp70h of closterovirids were similar, and in both cases the viruses separated into three clades, corresponding to the currently recognised genera.

Four shorter clones were obtained following RT-PCR with the Hsp70h degenerate primers of Tian et al. (1996) and alignments of an overlapping region of the Hsp70h equivalent to F11-F186 of GLRaV3-NYI were made. The $90 \%$ aa sequence identity criterion for the Hsp70h gene for species delimitation (Fauquet

Table 2. Percentage amino acid sequence identities of PMWaV-5 with other members of the Closteroviridae calculated from the pairwise comparison of regions within the helicase, RNA-dependent RNA polymerase (RdRp), open reading frame 2 (ORF2) and heat shock protein 70 homologue (Hsp70h), equivalent to $G_{1939}-G_{2232}, F_{2342}-V_{2739}$, $\mathrm{M}_{1}-\mathrm{V}_{\mathbf{4 5}}$ and $\mathrm{F}_{\mathbf{1 1}}-\mathrm{F}_{\mathbf{1 8 6}}$ of GLRaV-3-NYI, respectively

Virus acronyms and accession codes are as listed in Figs 2 and 3. Values were calculated from comparisons of either a single or multiple sequences of each virus species depending on sequence availability

\begin{tabular}{lcccc}
\hline Virus & \multicolumn{4}{c}{ PMWaV-5 } \\
& Helicase & RdRp & ORF2 & Hsp70h \\
\hline PMWaV-1 & 63.8 & $69.0-70.3$ & 53.5 & $72.7-73.3$ \\
PMWaV-2 & 30.2 & 36.5 & 14 & 37.2 \\
PMWaV-3 & - & $66.4-67.7$ & 53.5 & $68.0-69.2$ \\
PMWaV-4 & - & - & - & 77.3 \\
GLRaV-1 & 29.4 & 34.6 & 14 & $32.6-33.7$ \\
GLRaV-2 & 30.2 & 33.3 & - & 32.0 \\
GLRaV-3 & 28.3 & 34.1 & 27.9 & 37.8 \\
CTV & 31.7 & 32.0 & - & 28.5 \\
CYSDV & 27.9 & 24.7 & - & 24.4 \\
BYV & 29.1 & 31.2 & - & 27.9 \\
BYSV & 31.7 & 32.8 & - & 30.2 \\
LIYV & 30.9 & 27.6 & - & 22.1 \\
\hline
\end{tabular}


et al. 2005) was applied. One sequence (GenBank accession EF488752) had 98.8\% identity with PMWaV-1. Another two sequences (GenBank accessions EF488755 and EF488754) had $95.3 \%$ aa identity to each other and were at least $94.0 \%$ identical to the previously described aa sequence of PMWaV-3 from Australia (GenBank accession EF467918). The remaining sequence (GenBank accession EF488753) had less than $78 \%$ aa identity to any previously described closterovirid (Table 2) but had $99.2 \%$ identity over an overlapping stretch of 117 aa with the previously described sequence of PMWaV-5 (GenBank accession EF467920). Further evidence that PMWaV-5 is a distinct species was obtained by analysis of the helicase gene (Table 2).

In a phylogenetic analysis based on the $\mathrm{RdRp}$ region, two distinct clades of ampeloviruses were observed and supported by strong quartet puzzling values. One clade contained PMWaV-1, -3 and -5 and the second, GLRaV-1 and -3 and PMWaV-2 (Fig. 2). These evolutionary groupings were supported by a second phylogenetic analysis using the Hsp70h protein, for which a similar tree topology was observed (Fig. 3).

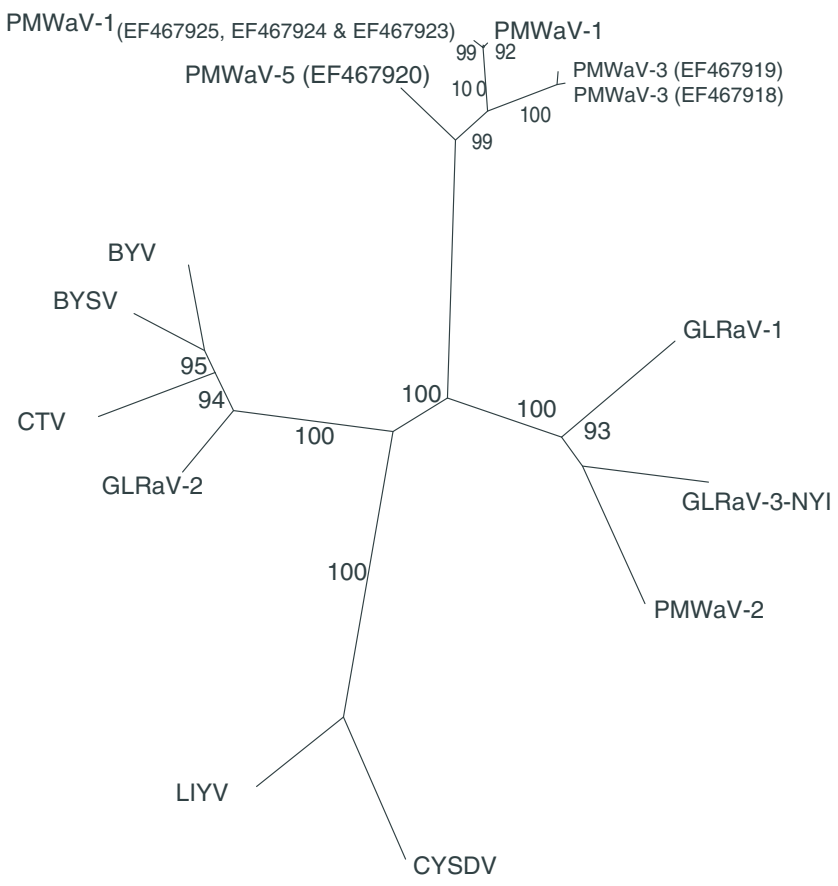

0.1

Fig. 2. Unrooted tree illustrating the relationships within family Closteroviridae based on the RNA-dependent RNA polymerase [region equivalent to $\left(\mathrm{F}_{2342}-\mathrm{V}_{2739}\right)$ of GLRaV3-NYI]. Values in the nodes of the branches are from 1000 steps of quartet puzzling. Virus acronyms and GenBank accession codes are as follows: Pineapple mealybug wiltassociated virus 1 (PMWaV-1; AF414119), Pineapple mealybug wiltassociated virus 2 (PMWaV-2; AF283103), Grapevine leafroll-associated virus 1 (GLRaV-1; AF195822), Grapevine leafroll-associated virus 2 (GLRaV-2; AF039204), Grapevine leafroll-associated virus 3 (GLRaV-3; AF037268), Beet yellows virus (BYV; AF056575), Beet yellow stunt virus (BYSV; U51931), Citrus tristeza virus (CTV; U16304), Cucurbit yellow stunting disorder virus (CYSDV; NC004809) and Lettuce infectious yellows virus (LIYV; U15440).
Development of a diagnostic RT-PCR-MTPD assay for the pineapple ampeloviruses

To simultaneously detect PMWaV-1, $-2-3$ and -5 , the degenerate primers PCVDF1 and PCVDR1 were designed to conserved sequences in the helicase and RdRp regions of ORF 1, respectively. All four viruses, whether present as single or mixed infections, were amplified using these primers, giving similar sized products of $\sim 350 \mathrm{bp}$ (Fig. 4). To differentiate each individual virus, a MTPD assay was developed. Typically, for any homologous combination of virus and probe, $\mathrm{A}_{410 \mathrm{~nm}}$ values after $2-3 \mathrm{~h}$ incubation with enzyme substrate were $0.1-1.8$, compared with $0-0.03$ for heterologous combinations of virus and probe or the buffer controls. Where samples gave marginal $\mathrm{A}_{410 \mathrm{~nm}}$ values (0.04-0.09), they were retested to confirm results. When comparing the results from our RT-PCR-MTPD assays with those obtained using alternative specific assays, previously published for PMWaV-1 (TBIA, Hu et al. 1997) and -2 (RT-PCR, Sether et al. 2001), we observed for the 227 samples tested, a 92.9 and a $98.7 \%$ correlation in the

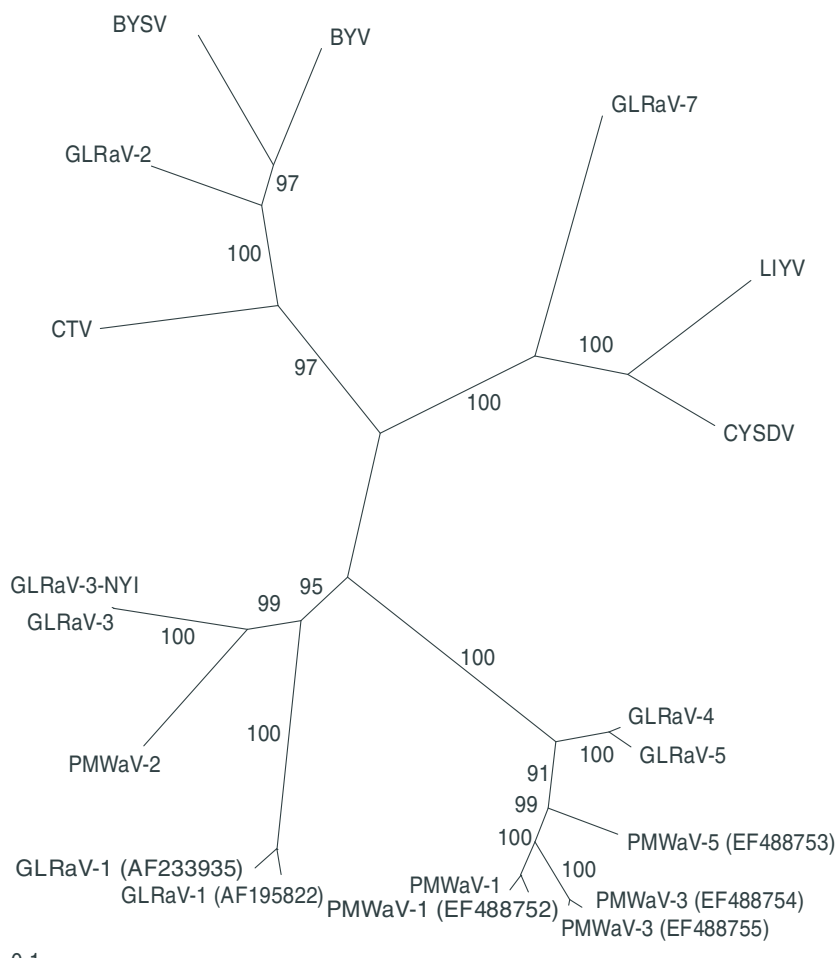

0.1

Fig. 3. Unrooted tree illustrating relationships within family Closteroviridae based on comparisons of the heat shock protein 70 homologue (region equivalent to $\left(\mathrm{F}_{11}-\mathrm{F}_{186}\right)$ of GLRaV3-NYI). Values in the nodes of the branches are from 1000 steps of quartet puzzling. Virus acronyms and GenBank accession codes are as described in Fig. 2 or as follows: BYV (X73476), BYSV (U51931), CTV (U16304), GLRaV-1 (AF233935 and AF195822), GLRaV-2 (Y14131), GLRaV-3 (AY424408 and AF037268), GLRaV-2 (AF039204), Grapevine leafroll-associated virus 4 (GLRaV-4; AF039553), Grapevine leafroll-associated virus 5 (GLRaV-5; AF039552), Grapevine leafroll-associated virus 7 (GLRaV-7; Y15987), LIYV (U15441), CYSDV (U67448), PMWaV-1 (AF414119) and PMWaV-2 (AF283103). 


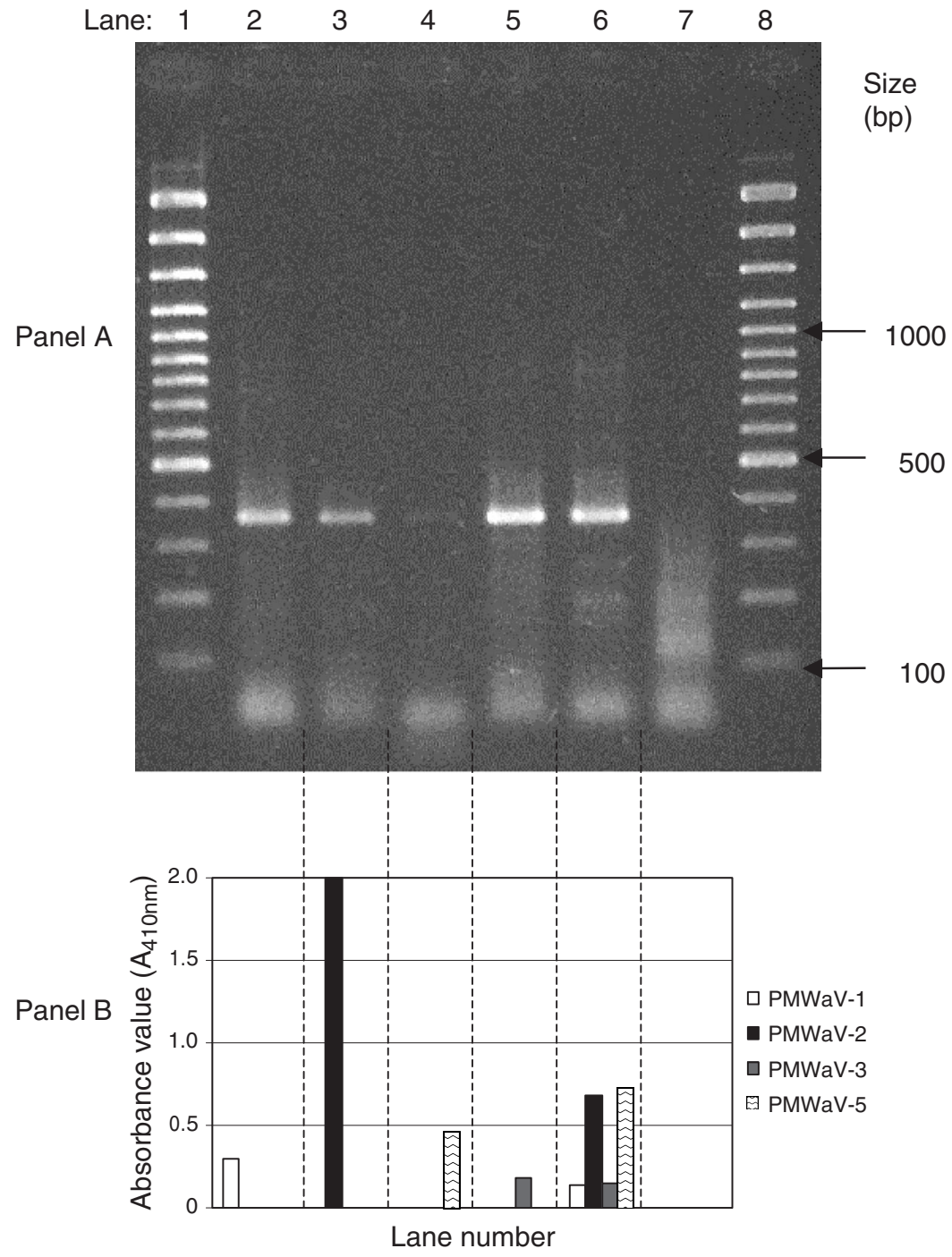

Fig. 4. Detection of the pineapple ampeloviruses by reverse transcription (RT)-PCR using the degenerate primers PCVDF1 and PCVDR1 (panel A) and differentiation of the PCR amplicons by microtitre plate detection (panel B). For panel A, the order of loading is: lanes 1 and 8 are 100 base pair marker (Fermentas), lanes $2-5$ are plants infected with PMWaV-1, $-2,-5$ or -3 , respectively, lane 6 is a plant infected with all four viruses and lane 7 is an uninfected pineapple plant. For panel B, each RT-PCR was tested for all four viruses using specific probes and results after a 2-h substrate incubation time are given.

detection of PMWaV-1 and -2 , respectively. Using the TBIA, PMWaV-1 was detected in 159 of 175 infected samples whereas using our assay the virus was detected in 174 of 175 infected samples. Using the specific RT-PCR assay, PMWaV-2 was not detected in 2 of 61 infected samples identified with RT-PCR-MTPD.

\section{Disease surveys}

The aetiology of MWD was investigated in four commercial Smooth Cayenne crops in south-east Qld in 2002-03. Diseased plants mostly occurred along the edges of the crops. Typical symptoms included reddening of the leaf, leaf tip necrosis and downward rolling of the leaf margins (Fig. 5). Leaf reddening was more prominent in the F180 and C 30 clones as compared with the hybrid plants. In the two crops that were revisited after 3 months (sites 1 and 2), some recovery of the diseased plants was noted with fruit being produced; none of the tagged symptomless plants had succumbed to MWD. All plants from sites 2 and 3, irrespective of symptoms, were infected with at least one ampleovirus (Table 3). By contrast, $47.2 \%$ of hybrid plants (site 1) and $27.5 \%$ of the F180 plants (site 4) had no detectable ampeloviruses and most were also symptomless. Overall, PMWaV-1 and PMWaV-3 were the most frequently detected viruses, being found in 78.5 and $67.5 \%$, respectively, of all plants tested. PMWaV-2 and -5 were detected in less than $25 \%$ of all plants tested. 
(a)

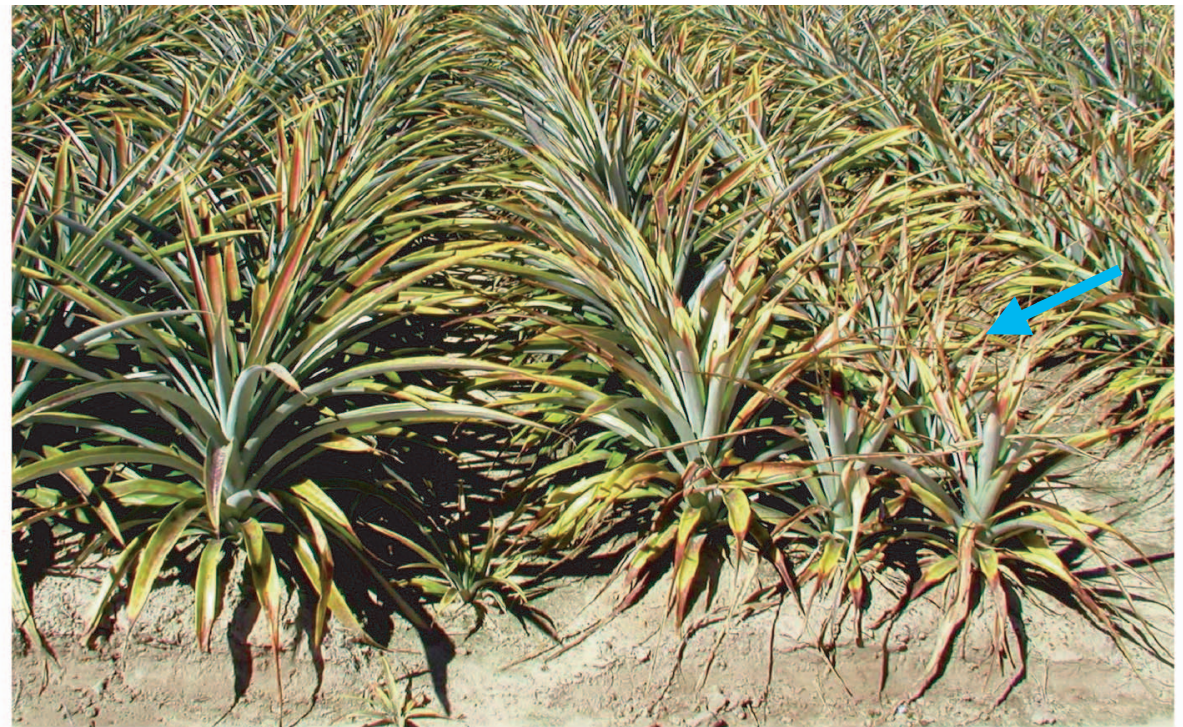

(b)

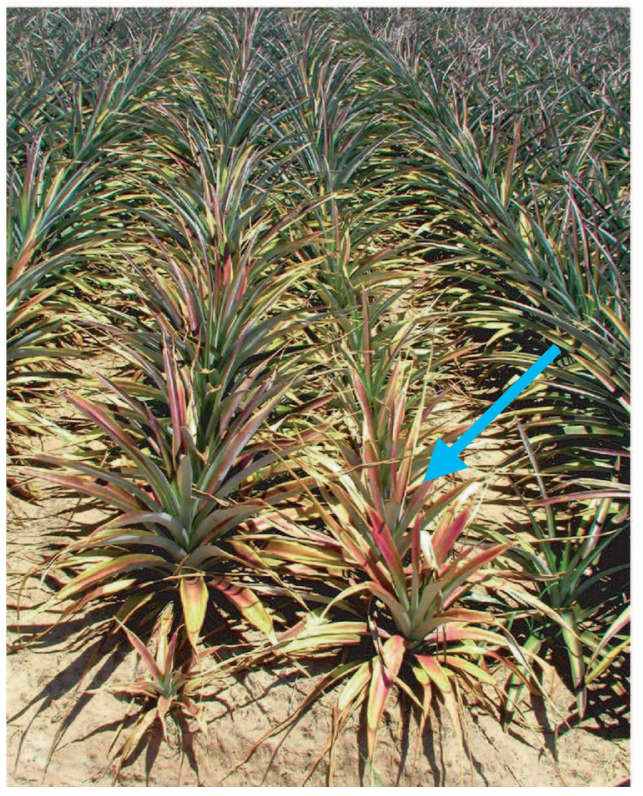

(c)

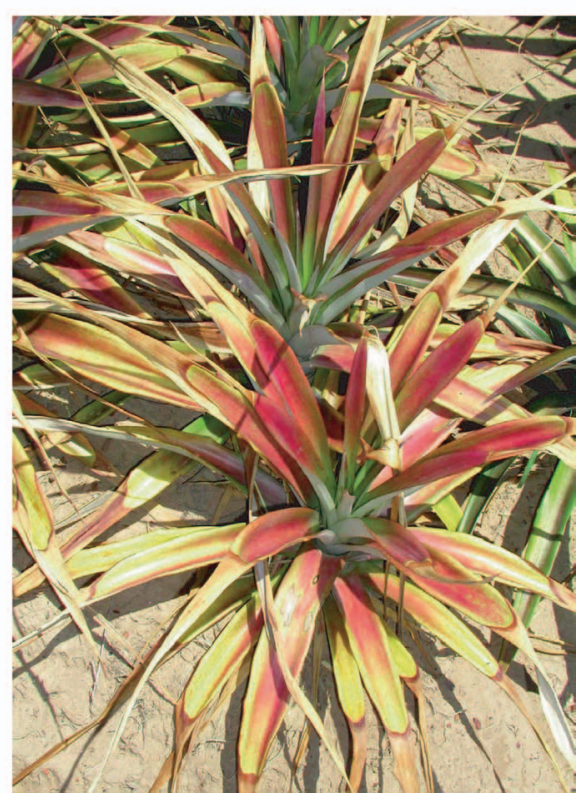

Fig. 5. Symptoms of mealybug wilt disease (MWD) in C30 pineapples at site $3(a)$ and in F180 pineapples at site $2(b$ and $c)$. Symptoms of MWD include leaf tip dieback and downward rolling of the leaf margins. Examples of diseased plants are highlighted with an arrow and in $(c)$. PMWaV-2 was detected in most of the disease-affected plants that were tested from site 3 whereas PMWaV-3 was strongly associated with MWD at site 2.

There was a highly significant association between the presence of PMWaV-3 and MWD $(P<0.001)$ at sites 1 , 2 and 4, where the virus was detected in $88-91 \%$ of the MWD-affected plant population but only in $16-18 \%$ of the asymptomatic plant population. Also at sites 1 and 4, there was a highly significant association between PMWaV-1 and MWD $(P<0.001)$, where the virus was detected in $78 \%$ of the MWD-affected plant population but only in $20 \%$ of the asymptomatic plant population. At site 3, PMWaV-1 and PMWaV-3 were detected in all plants that were sampled, irrespective of disease symptoms. Only at site 3 was there a highly significant association between the presence of PMWaV-2 and MWD symptoms $(P<0.001)$, where the virus was detected in $83 \%$ of the MWD-affected plant population but only detected in $2 \%$ of the asymptomatic plant population. There was no significant association between PMWaV-5 and MWD at any of the sites.

Although many different combinations of the four viruses were detected in the survey samples (Table 3), no particular combination was consistently associated with MWD. The 
Table 3. The incidences of PMWaV-1, $-2,-3$ and -5 in four commercial pineapple crops from south-east Queensland as single or mixed infections

Plants were rated as symptomless $(\mathrm{H})$ or affected by mealybug wilt disease (D). Total numbers of plants infected by each virus are listed in the bottom half of the table

\begin{tabular}{|c|c|c|c|c|c|c|c|c|}
\hline \multirow[t]{2}{*}{ Virus status } & \multicolumn{2}{|c|}{ Site $1^{\mathrm{A}}$} & \multicolumn{2}{|c|}{ Site $2^{\mathrm{B}}$} & \multicolumn{2}{|c|}{ Site $3^{\mathrm{C}}$} & \multicolumn{2}{|c|}{ Site $4^{\mathrm{D}}$} \\
\hline & $\mathrm{H}$ & $\mathrm{D}$ & $\mathrm{H}$ & $\mathrm{D}$ & $\mathrm{H}$ & $\mathrm{D}$ & $\mathrm{H}$ & $\mathrm{D}$ \\
\hline PMWaV-1 & 1 & 1 & 17 & 1 & 0 & 0 & 3 & 2 \\
\hline PMWaV-2 & 1 & 0 & 0 & 0 & 0 & 0 & 1 & 0 \\
\hline PMWaV-3 & 0 & 1 & 0 & 1 & 0 & 0 & 1 & 5 \\
\hline PMWaV-5 & 0 & 1 & 0 & 0 & 0 & 0 & 1 & 0 \\
\hline PMWaV-1 and -2 & 0 & 0 & 0 & 3 & 0 & 0 & 1 & 1 \\
\hline PMWaV-1 and -5 & 0 & 1 & 1 & 0 & 0 & 0 & 0 & 0 \\
\hline PMWaV-1 and -3 & 1 & 6 & 2 & 11 & 34 & 3 & 1 & 10 \\
\hline PMWaV-2 and -5 & 0 & 0 & 0 & 0 & 0 & 0 & 1 & 0 \\
\hline PMWaV-3 and -5 & 0 & 0 & 0 & 2 & 0 & 0 & 0 & 0 \\
\hline PMWaV-1, -2 and -3 & 0 & 1 & 0 & 1 & 0 & 18 & 0 & 2 \\
\hline PMWaV-1, -3 and -5 & 1 & 4 & 0 & 4 & 5 & 4 & 0 & 0 \\
\hline PMWaV-1, $-2,-3$ and -5 & 0 & 0 & 0 & 1 & 1 & 15 & 0 & 0 \\
\hline $\mathrm{NVD}^{\mathrm{E}}$ & 16 & 1 & 0 & 0 & 0 & 0 & 11 & 0 \\
\hline Total plants sampled & 20 & 16 & 20 & 24 & 40 & 40 & 20 & 20 \\
\hline \multicolumn{9}{|l|}{$\begin{array}{l}\text { Total infected } \\
\text { with each virus }{ }^{\mathrm{F}}\end{array}$} \\
\hline PMWaV-1 & 3 & 13 & 20 & 21 & 40 & 40 & 5 & 15 \\
\hline PMWaV-2 & 1 & 1 & 0 & 5 & 1 & 33 & 3 & 3 \\
\hline PMWaV-3 & 2 & 12 & 2 & 20 & 40 & 40 & 2 & 17 \\
\hline PMWaV-5 & 1 & 6 & 1 & 7 & 6 & 19 & 2 & 0 \\
\hline
\end{tabular}

${ }^{\mathrm{A}}$ Site 1 is a hybrid A crop located at Beerwah.

${ }^{\mathrm{B}}$ Site 2 is a F180 crop located in the Glasshouse Mountains.

${ }^{\mathrm{C}}$ Site 3 is a $\mathrm{C} 30$ crop located in the Glasshouse Mountains.

${ }^{D}$ Site 4 is a F180 crop located at Gympie.

${ }^{\mathrm{E}} \mathrm{NVD}$, no virus detected.

${ }^{\mathrm{F}}$ Total infected with each virus either singly or in combination with one of the other viruses.

number of different ampelovirus species infecting a plant varied between sites. For example, the majority of diseased plants from sites 1 and 4 were infected with one or two ampelovirus species whereas those from site 3 were infected with three or four species.

\section{Viruses present in germplasm collections}

PMWaV-1, -2 and -3 were found in both the MRS and CIRAD pineapple germplasm collections (Table 4). In addition to these viruses, PMWaV-5 was also detected in three accessions from the CIRAD collection. The most frequently detected virus from the MRS collection was PMWaV-3 whereas PMWaV-1 was found more often in plants tested from the CIRAD collection. Mixed infections were common in accessions from both collections. Four accessions did not contain any detectable ampelovirus by RT-PCR, TBIA or ISEM (Table 4).

\section{Mealybug transmissions}

In transmission experiments using $D$. brevipes, the dual infection of PMWaV-1 and -3 was transmitted to 3 of the 5 test plants. In a separate experiment, PMWaV-2 was transmitted to 2 of 10 test plants by $D$. brevipes. Although PMWaV-1 was also present in the virus source plants in this test there was no transmission of this virus to any of the test plants. No symptoms developed in any plants in either test.

\section{Discussion}

PMWaV-1, -2 and -3 and a previously undescribed ampelovirus, for which we propose the name PMWaV-5, have been detected in Australian pineapples. Sequence comparisons and phylogenetic analyses indicate that PMWaV-3 and -5 are distinct species, most closely related to $\mathrm{PMWaV}-1$ and only distantly related to PMWaV-2. This supports the previous report of Sether et al. (2005a) that PMWaV-3 is a distinct virus species. Intraspecies sequence diversity for PMWaV-1 and -3 has not been previously reported. From this study, the variation in $\mathrm{RdRp}$ aa sequences is at least 4.2 and $7.8 \%$ for isolates of PMWaV-1 and -3 , respectively.

A diagnostic assay allowing simultaneous detection of PMWaV-1, -2, -3 and -5 was developed and used in virus surveys, thus reducing the cost and time required for testing. Probes and degenerate PCR primers were used for detection to avoid the potential problem of specific PCR primers failing to detect virus isolates with minor sequence variation. Overall, the incidence of PMWaV-2 and -5 in Australian commercial pineapple crops was low. These viruses may have been a more recent or less frequent introduction into Australian pineapples resulting in more limited spread. In contrast, PMWaV-1 and -3 were found to be more widespread and may have been present in Australia for a longer time. PMWaV-3 was shown in this study to be transmitted by $D$. brevipes and although the vector of PMWaV-5 has not yet been identified, from the phylogenetic analyses presented in this paper, it is also likely to be a mealybug species.

Previous research has implicated PMWaV-2 as the cause of MWD but only in combination with mealybug feeding (Sether and $\mathrm{Hu} 2002 b$ ). However, in our field studies, there was only one survey site (site 3) where a strong association between MWD and infection with PMWaV-2 was observed. Also at this site, PMWaV-1 and PMWaV-3 were detected in all plants sampled, regardless of disease status. The incidence of PMWaV-2 in the remaining three surveyed crops was low and where present there was no clear association with disease. At these remaining sites the presence of PMWaV-3 was strongly associated with MWD, and at sites 1 and 4 PMWaV-1 was also strongly associated with the disease. PMWaV-5 was not associated with MWD at any of the sites studied. There were no observable mealybug colonies present on survey plants and the combined effect of virus presence and insect feeding was not evaluated in this study. The aetiology of MWD in the Australian pineapple crops studied was thus not consistent with the situation reported from Hawaii. PMWaV-1 and -3 were associated with the disease at some study sites but uniformly detected in all plants from another site.

Other viruses are known to occur in pineapple in Australia. Bacilliform virions has been detected in pineapple plants from Australia and Hawaii (Wakman et al. 1995; Sether and $\mathrm{Hu} 2002 a$ ), and the presence of two distinct badnavirus species in Australian-grown Ananas spp. has been confirmed (C. F. Gambley, V. Steele, A. D. W. Geering and J. E. Thomas, unpubl. data). Isometric virions have also been observed in virus preparations from Australian pineapple root 
Table 4. Ampeloviruses detected in accessions from germplasm collections maintained at the Maroochy Research Station (MRS), Australia and at the Centre de coopération internationale en recherche agronomique pour le développement (CIRAD), Martinique

\begin{tabular}{|c|c|c|c|c|c|c|c|}
\hline Species & Cultivar & Location & $\begin{array}{l}\text { DPI\&F } \\
\text { accession }\end{array}$ & $\begin{array}{l}\text { Virus detected by } \\
\text { RT-PCR-MTPD }\end{array}$ & $\begin{array}{l}\text { ISEM } \\
\text { result }^{\mathrm{A}}\end{array}$ & $\begin{array}{c}\text { PMWaV-2 PCR } \\
\text { result }^{\mathrm{B}}\end{array}$ & $\begin{array}{l}\text { TBIA } \\
\text { result }^{\mathrm{C}}\end{array}$ \\
\hline $\begin{array}{l}\text { Ananas comosus var. } \\
\text { ananassoides }\end{array}$ & FRF223 & MRS & FrD1213 & $\begin{array}{l}\text { Pineapple mealybug } \\
\quad \text { wilt associated virus } \\
\text { (PMWaV)-3 }\end{array}$ & + & - & - \\
\hline A. comosus var. ananassoides & FRF361 & MRS & FrD1214 & PMWaV-1 and -3 & + & - & + \\
\hline A. comosus var. bracteatus & FRF414 & MRS & FrD1220 & PMWaV-3 & + & - & - \\
\hline A. comosus var. comosus & Perolera & MRS & FrD1231 & PMWaV-1, -2 and -3 & NT & + & +++ \\
\hline A. comosus var. comosus & Primavera & MRS & FrD1228 & PMWaV-2 and -3 & + & + & - \\
\hline A. comosus var. comosus & Tapiricanga & MRS & FrD1227 & PMWaV-2 & + & + & - \\
\hline A. comosus var. comosus & Eleuthera & MRS & FrD1230 & PMWaV-1, -2 and -3 & + & + & + \\
\hline A. comosus var. comosus & Alexander Queen & MRS & FrD1225 & PMWaV-1, -2 and -3 & + & + & - \\
\hline A. comosus var. comosus & Mauritius Queen & MRS & FrD1229 & PMWaV-1, -2 and -3 & + & + & + \\
\hline A. comosus var. comosus & Masmerah & MRS & FrD1224 & PMWaV-1, -2 and -3 & NT & + & + \\
\hline A. comosus var. comosus & Roja Espanola & MRS & FrD1226 & PMWaV-2 and -3 & + & + & - \\
\hline A. comosus var. erectifolius & Selvagem 6 & MRS & FrD1217 & PMWaV-1, -2 and -3 & + & + & +++ \\
\hline A. comosus var. bracteatus & Fritzmuelleri & MRS & FrD1234 & NVD & - & - & - \\
\hline A. comosus var. comosus & Rondon & CIRAD & FrDQ1248 & NVD & - & - & - \\
\hline A. comosus var. erectifolius & Unknown & CIRAD & FrDQ1249 & PMWaV-1 and -2 & NT & + & - \\
\hline A. comosus var. comosus & Unknown & CIRAD & FrDQ1250 & PMWaV-1 & + & - & - \\
\hline A. comosus var. parguazensis & Unknown & CIRAD & FrDQ1245 & PMWaV-1 & ++ & - & - \\
\hline A. comosus var. ananassoides & Unknown & CIRAD & FrDQ1244 & PMWaV-1, -3 and -5 & + & - & - \\
\hline A. comosus var. bracteatus & Unknown & CIRAD & FrDQ1251 & NVD & - & - & - \\
\hline A. comosus var. comosus & Cayenne & CIRAD & FrDQ1246 & PMWaV-1, -2 and -3 & +++ & + & + \\
\hline A. comosus var. comosus & Red Spanish & CIRAD & FrDQ1247 & PMWaV-1, -2 and -3 & +++ & + & + \\
\hline A. comosus var. comosus & Perolera & CIRAD & FrDQ1241 & NVD & - & - & - \\
\hline A. comosus var. comosus & Queen & CIRAD & FrDQ1238 & PMWaV-1, -2 and -3 & +++ & + & +++ \\
\hline A. comosus var. unknown & Unknown & CIRAD & FrDQ1252 & PMWaV-1 & +++ & - & +++ \\
\hline A. comosus var. comosus & Cayenne & CIRAD & FrDQ1243 & PMWaV-1 and -3 & +++ & - & +++ \\
\hline A. comosus var. comosus & Queen & CIRAD & FrDQ1242 & PMWaV-1, -3 and -5 & +++ & - & - \\
\hline A. comosus var. comosus & Red Spanish & CIRAD & FrDQ1237 & PMWaV-1, -2 and -3 & ++ & + & ++ \\
\hline
\end{tabular}

${ }^{\mathrm{A}}$ Immunosorbent electron microscopy result rated as -, no virus detected; + , low virus titre; ++ , medium virus titre; +++ , high virus titre; NT, not tested. ${ }^{B}$ PMWaV-2 PCR result rated as -, no virus detected; + , positive reaction with specific primers (Sether et al. 2001).

${ }^{\mathrm{C}}$ Tissue blotting immunoassay result rated as - , no reaction; + , weak reaction; ++ , moderate reaction; +++ , high reaction to the PMWaV-1 MAb.

tissue. The virions were subsequently partially characterised and at least two new species of the family Sadwaviridae identified (Thompson et al. 2005). There has been no comprehensive investigation to determine if any these viruses are associated with MWD either alone or in combination with the ampeloviruses.

The results of this study provide no consistent association between the presence of an individual virus and MWD across south-east Qld. An association is only circumstantial evidence of causality and as such the causal agent of MWD in Australia will remain unconfirmed until there is successful completion of Koch's postulates. It is possible several viruses can contribute, alone or in combination, to the disease and that MWD is a more general syndrome resulting from ampelovirus infection of pineapple. Alternatively a synergistic interaction could occur between two different types of viruses, where one may release the silencing mechanism on the other.

\section{Acknowledgements}

We thank Mr Murray Sharman (DPI\&F) for his assistance with virus purification, Mrs Vivienne Doogan (DPI\&F) for statistical analyses,
Dr Elizabeth Aitken (University of Queensland) for helpful discussions, Dr Garth Sanewski (DPI\&F) and Jean-Pierre Horry from CIRAD, Martinique for the supply of pineapple germplasm accessions and Dr J. S. Hu, Dr D. M. Sether and M. Melzer (University of Hawaii) for unpublished sequences. We also thank Horticulture Australia Limited, Golden Circle and The University of Queensland for funding.

\section{References}

Altschul SF, Gish W, Miller W, Myers EW, Lipman DJ (1990) Basic local alignment search tool. Journal of Molecular Biology 215, 403-410.

Carter W (1933a) The pineapple mealybug, Pseudococcus brevipes, and wilt of pineapples. Phytopathology 23, 207-242.

Carter W (1933b) The spotting of pineapple leaves caused by Pseudococcus brevipes, the pineapple mealybug. Phytopathology 23, 243-259.

Carter W (1945) Some etiological aspects of mealybug wilt. Phytopathology 35, 305-315.

Carter W, Collins JL (1947) Resistance to mealybug wilt of pineapple with special reference to a cayenne-queen hybrid. Phytopathology 37, 332-348.

Dolja VV, Kreuze JF, Valkonen JPT (2006) Comparative and functional genomics of closteroviruses. Virus Research 117, 38-51. doi: 10.1016/ j.virusres.2006.02.002 
Fauquet CM, Mayo MA, Maniloff J, Desselberger U, Ball LA (2005) Family Closteroviridae. In 'Virus taxonomy. Eighth report of the international committee on taxonomy of viruses'. (Eds CM Fauquet, MA Mayo, J Maniloff, U Desselberger, LA Ball) pp. 1077-1087. (Elsevier Academic Press: San Diego, CA)

Fazeli CF, Rezaian MA (2000) Nucleotide sequence and organization of ten open reading frames in the genome of Grapevine leafroll-associated virus 1 and identification of three subgenomic RNAs. Journal of General Virology 81, 605-615.

Gambley CF, Thomas JE (2001) Molecular characterisation of Banana mild mosaic virus, a new filamentous virus in Musa spp. Archives of Virology 146, 1369-1379. doi: 10.1007/s007050170097

Geering ADW, McMichael LA, Dietzgen RG, Thomas JE (2000) Genetic diversity among Banana streak virus isolates from Australia. Phytopathology 90, 921-927.

German TL, Ullman DE, Gunasinghe UB (1992) Mealybug wilt of pineapple. In 'Advances in disease vector research'. (Ed. KF Harris) pp. 242-259. (Springer-Verlag: New York)

Gunasinghe UB, German TL (1989) Purification and partial characterisation of a virus from pineapple. Phytopathology 79, 1337-1341. doi: 10.1094/ Phyto-79-1337

Horlock C (2003) Detection and elimination of mealybug wilt-associated viruses in pineapple. MA Thesis, Department of Microbiology and Parasitology, The University of Queensland, Brisbane.

Hu JS, Sether DM, Ullman DE (1996) Detection of pineapple closterovirus in pineapple plants and mealybugs using monoclonal antibodies. Plant Pathology 45, 829-836. doi: 10.1111/j.1365-3059.1996.tb02892.x

Hu JS, Sether DM, Liu XP, Wang M (1997) Use of a tissue blot immunoassay to examine the distribution of pineapple closterovirus in Hawaii. Plant Disease 81, 1150-1154. doi: 10.1094/PDIS.1997.81.10.1150

Illingworth JF (1931) Preliminary reports on evidence that mealybugs are an important factor in mealybug wilt. Journal of Economic Entomology 24, 877-889.

Ito K (1959) Terminal mottle as a symptomatological aspect of mealybug wilt with evidence supporting the hypothesis of a virus etiology of the disease. Report number 62. Pineapple Research Institute, Honolulu, Hawaii.

Kumar S, Tamura K, Nei M (2004) MEGA3: integrated software for molecular evolutionary genetics analysis and sequence alignment. Briefings in Bioinformatics 5(2), 150-163.

Melzer MJ, Karasev AV, Sether DM, Hu JS (2001) Nucleotide sequence, genome organization and phylogenetic analysis of pineapple mealybug wilt-associated virus-2. Journal of General Virology 82, 1-7.

Rott ME, Jelkmann W (2001) Detection and partial characterization of a second closterovirus associated with little cherry disease, Little cherry virus-2. Phytopathology 91, 261-267. doi: 10.1094/ PHYTO.2001.91.3.261

Sambrook J, Fritsch EF, Maniatis T (1989) 'Molecular cloning.' (Cold Spring Harbor Laboratory Press: Plainview, NY)

Schmidt HA, Strimmer K, von Haeseler A (2004) Tree-puzzle maximum likelihood analysis for nucelotide, amino acid and two-state data. Version 5.2. Available at www.tree-puzzle.de/ [Verified 2 December 2007]

Sether DM, Hu JS (2001) The impact of Pineapple mealybug wilt-associated virus-1 and reduced irrigation on pineapple yield. Australasian Plant Pathology 30, 31-36. doi: 10.1071/AP00060
Sether DM, Hu JS (2002a) Yield impact and spread of Pineapple mealybug wilt associated virus-2 and mealybug wilt of pineapple in Hawaii. Plant Disease 86, 867-874. doi: 10.1094/PDIS.2002.86.8.867

Sether DM, Hu JS (2002b) Closterovirus infection and mealybug exposure are necessary for the development of mealybug wilt of pineapple disease. Phytopathology 92, 928-935. doi: 10.1094/PHYTO.2002.92.9.928

Sether DM, Karasev AV, Okumura C, Arakawa C, Zee F, Kisian MM, Busto JL, Hu JS (2001) Differentiation, distribution and elimination of two different pineapple mealybug wilt-associated viruses found in pineapple. Plant Disease 856-864.

Sether DM, Melzer MJ, Busto J, Zee F, Hu JS (2005a) Diversity and mealybug transmissibility of ampeloviruses in pineapple. Plant Disease 89, 450-456. doi: 10.1094/PD-89-0450

Sether DM, Melzer MJ, Subere CV, Hu JS (2005b) Pineapple mealybug wilt associated viruses 1, 3, and 4, and Grapevine leafroll associated viruses 4, 5, 6, and 9 are a distinct group in the genus Ampelovirus. In 'Abstracts of the XIII international congress of virology'. pp. 121-122. Abstract V-68. (American Society for Microbiology: Washington, DC)

Sharman M, Thomas JE, Dietzgen RG (2000) Development of a multiplex immunocapture PCR with colormetric detection for viruses of banana. Journal of Virological Methods 89, 75-88. doi: 10.1016/S01660934(00)00204-4

Thompson H, Botella J, Fairbairn D, Moyle R, Thomas JE, Sharman M, Aitken EA, Geering ADW (2005) Characterisation and detection of isometric viruses in pineapple. In 'Proceedings of the 15th biennial Australasian plant pathology conference'. p. 318. (Australasian Plant Pathology Society: Geelong, Vic.)

Thompson JD, Gibson TJ, Plewniak F, Jeanmougin F, Higgins DG (1997) The ClustalX windows interface: flexible strategies for multiple sequence alignment aided by quality analysis tools. Nucleic Acids Research 25, 4876-4882. doi: 10.1093/nar/25.24.4876

Thomson KG, Dietzgen RG, Thomas JE, Teakle DS (1996) Detection of pineapple bacilliform virus using the polymerase chain reaction. Annals of Applied Biology 129, 57-69.

Tian T, Klaassen VA, Soong J, Wisler G, Duffus JE, Falk BW (1996) Generation of cDNAs specific to lettuce infectious yellows closterovirus and other whitefly-transmitted viruses by RT-PCR and degenerate oligonucleotide primers corresponding to the closterovirus gene encoding the heat shock protein 70 homolog. Molecular Plant Pathology 86, 1167-1173.

Wakman W, Teakle DS, Thomas JE, Dietzgen RG (1995) Presence of a clostero-like virus and a bacilliform virus in pineapple plants in Australia. Australian Journal of Agricultural Research 46, 947-958. doi: 10.1071/AR9950947

Williams DJ (1985) 'Australian mealybugs.' (British Museum of Natural History: London)

Manuscript received 4 June 2007, accepted 25 November 2007 